\title{
THE ENFORCEMENT OF JUDGMENTS FOR POSSESSION OF LAND
}

\section{David Capper, Senior Lecturer in Law, Queen's University Belfast*}

Where a court or tribunal orders an occupier of real property to deliver possession of the land to another, usually the owner, one is tempted to assume that all legal issues between the parties have been resolved. All that remains to be done, one would think, is for physical possession of the land to be given to the person now entitled to it. This article considers to what extent this is true and whether the established procedure for the enforcement of orders for the delivery of possession can, or must, make the person entitled to possession jump through any further legal hoops.

The typical cases under consideration here are those where a mortgagee of land has been granted possession of the land to enable it to sell the land and apply the proceeds towards an unpaid secured loan; or, where a lessor has obtained an order requiring the lessee to vacate the land and allow the lessor to resume exclusive possession. The article is not concerned with orders charging land under article 46 of the Judgments (Enforcement) (Northern Ireland) Order 1981, a process which has created a minefield of problems relating to the obtaining of possession to facilitate sale of the property. ${ }^{1}$ The latter is a means of enforcing a money judgment, not an order for the possession of land. The order charging land is granted to secure the money judgment, with the process of obtaining possession coming later and designed to enable the land to be sold to realise money for the discharge of the judgment debt.

Before analysing the position with regard to judgments or orders for the possession of land it is worth outlining what is involved in the enforcement of a money judgment.

\section{Money Judgments}

As any hard bitten business creditor can tell you the obtaining of a judgment for debt or damages in no way equates to payment of the sum adjudged due. The debtor may be unable to pay because of insolvency, or may be experiencing cash flow problems and unable to pay at the moment, or the debtor may be either disorganised or bloody minded and simply unwilling to settle the debt.

For debtors of the latter sort the creditor may have to go through the frequently wearisome process of enforcement through the Enforcement of Judgments Office (hereafter the "Office"), in accordance with the procedure laid down by the Judgments (Enforcement) (Northern Ireland) Order 1981

\footnotetext{
* The author would like to thank Dr Heather Conway and Master J Christopher Napier who read and commented upon an earlier version of this article. They are responsible for effecting significant improvements to this article but the author remains responsible for any errors.

${ }^{1}$ On this see Conway, Co-Ownership of Land - Partition Actions and Remedies (Dublin, 2000) pp 188-195, 235-239.
} 
(hereafter the "1981 Order"). ${ }^{2}$ The description just given of this process is not meant to convey the impression that staff working in the Office are obstructive of creditors trying to recover debts or that the system is some kind of conspiracy against creditors. It is simply a fact that any system for the enforcement of judgments which tries to be even handed between creditors and debtors, and which is intended to differentiate the "can't pay" from the "won't pay", is unlikely to be swift in the recovery of judgment debts.

That system depends very heavily upon rigorous examination of the debtor as to its means to pay the debt. ${ }^{3}$ For those debtors that the examination reveals are unable to pay a certificate of enforceability can be issued under article 19 of the 1981 Order, effectively preventing that judgment from being enforced until such times as the certificate is lifted under article 13(g)(iii). A prudent creditor may be able to avoid this frustrating conclusion by attempting to ascertain whether it is the likely result of enforcement by careful enquiries about the debtor before enforcement is commenced, or even before the claim is initiated. These enquiries, which only save the costs of enforcement and do not result in payment of the debt, may involve inspection of the register of judgments maintained by the Office ${ }^{4}$ to see if other unenforced judgments have been registered against the debtor, or may take the form of inquiries to credit reference agencies. For those debtors who can pay, whether now or with time, the examination should reveal which of a variety of enforcement orders ${ }^{5}$ would be most suited to enforcement of the debt. The process does not come cheap. In the Schedule to the Judgment Enforcement Fees Order (Northern Ireland) $1996,{ }^{6}$ as amended by an amending order of $1998,{ }^{7}$ a sliding scale of fees for enforcement is laid down depending on the amount of money due under the judgment. ${ }^{8}$

For non-business creditors, particularly consumers, the fact that a court judgment does not necessarily involve payment is frequently the cause of surprise and disgust. Many struggle to comprehend how they can be no better off, and sometimes even worse off, after a court has determined that they are entitled to payment. For many such creditors the enforcement fees just alluded to are daunting, especially when they are only recoverable if the judgment is enforceable. The sliding scale presents problems too because a very much larger proportion of smaller judgments (more likely to be the sort of judgments consumers would obtain) has to be paid in enforcement fees. ${ }^{9}$

${ }^{2}$ SI 1981/226 (NI 6).

${ }^{3}$ Under the provisions of articles $26-27$ of the 1981 Order.

${ }^{4}$ Under article $116(1)$ of the 1981 Order.

${ }^{5}$ Most of these can be found in Part V of the 1981 Order.

${ }^{6}$ SR 1996 No. 101.

${ }^{7}$ SR 1998 No. 411.

${ }^{8}$ E.g. For a debt not exceeding $£ 300$ the fee is $30 \mathrm{p}$ in $£$, subject to a minimum fee of $£ 30$. For debts in the $£ 1,000-3,000$ range the fee is $£ 210$ plus $£ 8.50$ per $£ 100$ or part $£ 100$ in excess of $£ 1,000$. For debts exceeding $£ 10,000$ the fee is $£ 645$ plus $£ 1.80$ per $£ 100$ or part $£ 100$ in excess of $£ 10,000$.

${ }^{9}$ The problems these fees presented for consumer creditors were highlighted in the Response of the General Consumer Council for Northern Ireland to the Interim Report of the Civil Justice Reform Group (General Consumer Council, Belfast, 1999) at pp 14-16. 
It should also be said that enforcement fees generally are a very much larger proportion of judgment debts than was originally envisaged by the Anderson Report which proposed the setting up of the current enforcement system in Northern Ireland. ${ }^{10}$

\section{Judgments for the Possession of Land}

As the introduction to this article suggested one would probably assume that a court or tribunal decision that possession of land should be given to the owner would leave very little more to decide before physical possession of the land was given. There is a need to apply for enforcement, the relevant fees being $£ 20$ for the application to enforce a non-money judgment and $£ 515$ for an order for delivery of possession of land. ${ }^{11}$ Again these fees are certainly not cheap and there is no sliding scale depending on the value of the land or anything else. But there is no need to examine the occupier as to what means it has for payment of the judgment, and there is no prospect of a certificate of unenforceability being granted because of inability to pay. Any considerations, such as hardship to the occupier, which might lead to possession being refused or stayed, seem logically to be matters for the court or tribunal called upon to decide whether possession should be delivered. Enforcement would not seem to be a process calling for any or any further consideration of these matters.

When the Anderson Working Party considered this matter it did not seem to envisage the Office having any real discretion to withhold or delay possession:-

"Whilst the making of an order for possession by the Office, in some cases where the Court has already made such an order, may appear to be unnecessary duplication, we consider that for this form of enforcement, as in the others, the notification to the judgment debtor of what is going to happen may, in some cases at least, have the effect of speeding enforcement, and in some cases enforcement may be effected without any further steps having to be taken." (emphasis added). ${ }^{12}$

Although clause 24(1) of the draft Enforcement of Judgments Bill contained in the Report stated, like article 53(1) of the 1981 Order does, that the Office "may" order delivery of possession, the use of this permissive word should be read in the light of the Report's recommendations. Section 53(1) of the Judgments (Enforcement) Act (Northern Ireland) 1969, the enactment giving effect to the enforcement system recommended by the Anderson Report, also contained the permissive word "may".

Despite this legislative history Murray LJ, in Allied Irish Banks plc v McAllister,${ }^{13}$ concluded that the Office did have a discretion to grant a stay of

10 See the Report of the Joint Working Party on the Enforcement of Judgments, Orders and Decrees of the Courts in Northern Ireland (Belfast, 1965) (the "Anderson Report") para 53.

11 Judgment Enforcement Fees Order (NI) 1996, art 4 and Schedule, as amended by by Judgment Enforcement Fees (Amendment) Order (NI) 1998, art 2.

12 Anderson Report, para 108.

13 [1993] NI 286. 
enforcement in mortgagee repossession cases. ${ }^{14}$ His Lordship based this on an analysis of the provisions of the 1981 Order generally, together with the Judgment Enforcement Rules (Northern Ireland) 1981 (hereafter the "1981 Rules"). ${ }^{15}$ In support of a literal meaning of "may" in article 53(1) article 13(f) of the 1981 Order states that, subject to any other statutory provision, the Office may stay enforcement of any judgment either absolutely or subject to such terms and conditions as it considers proper. Rule 103(1)(a) of the 1981 Rules allows the Master (Enforcement of Judgments) to grant a stay of enforcement when he is satisfied that there are special circumstances which render it inexpedient to enforce the judgment. Rule $103(6)^{16}$ states that no stay of enforcement shall be made in respect of a judgment given under Rules of the Supreme Court (Northern Ireland) 1980 Order 113 or a warrant issued under section 1(2) of the Summary Jurisdiction (Miscellaneous Provisions) Act (Northern Ireland) 1946. ${ }^{17}$ This supports the conclusion reached by Murray LJ, as the prohibition of a stay of enforcement in some possession cases suggests that it exists in all others. ${ }^{18}$

The wide and apparently untrammelled nature of the discretion conferred on the Office clearly troubled the learned judge. In mortgagee possession cases involving dwelling houses the court has an ostensibly wide discretion under section 36 of the Administration of Justice Act 1970 and section 8 of the Administration of Justice Act 1973 to give the mortgagor a reasonable time to pay and to withhold possession or grant a stay to enable him or her to do so. ${ }^{19}$ His Lordship could not see much sense in giving the court this discretion and then giving the Office another discretion to look at the question of possession again after the court had decided that the mortgagor was to be given no further time to pay. ${ }^{20}$ As a way of controlling this latter discretion Murray LJ suggested that it be exercised with regard to section 36 of the 1970 Act and section 8 of the 1973 Act. His Lordship explained this by reference to the words "subject to any other statutory provision" in article 13(f) of the 1981 Order. $^{21}$ With respect, this is not a convincing solution to the problem. If there is no sensible basis for the Office having an additional

14 His Lordship was careful to say that his judgment did not apply to any other proceedings; see [1993] NI 286 at 301 . This does not take away from the light which the judgment sheds on whether the Office has any discretion under article 53.

15 SR 1981 No 147.

16 Inserted by rule 3(2) of the Judgment Enforcement (Amendment No 2) Rules (Northern Ireland) 1983.

17 These provisions deal with squatters.

18 See [1993] NI 286 at 300.

19 This discretion seems to be exercised less generously to the mortgagor in Northern Ireland than it is in England and Wales. Contrast Cheltenham \& Gloucester Building Society v Norgan [1996] 1 WLR 343 with National \& Provincial Building Society v Lynd \& Anor [1996] NI 47.

20 See [1993] NI 286 at 300. His Lordship suggested that very little thought could have been given to this question when the 1981 Order was being prepared.

21 Ibid at 301. Murray LJ held that the six years allowed by the Master (Enforcement of Judgments) for discharge of arrears was too long. The mortgagor had offered to assign to the mortgagee his sheep farming subsidy of $£ 3,000$ per annum, which would have discharged the debt in about six years. 
discretion to the court's there is little more sense in cutting that discretion down, especially if it is to be cut down by reference to the court's discretion.

The problem gets worse when mortgages over properties not including a dwelling house are considered. ${ }^{22}$ Here there is no statutory discretion to stay mortgagee possession proceedings at all, only a very limited power for the court to adjourn or stay execution of an order for possession for a short time to see if the mortgagor can pay off the whole of the mortgage debt. ${ }^{23}$ So there would be no obvious way of reducing the discretion which a literal reading of the legislative provisions appears to confer. It cannot seriously be suggested that Parliament intended to make up for the absence of any discretion for the court to stay proceedings by granting the Office an apparently unrestricted discretion through the backdoor route of article 53(1) of the 1981 Order. None of this caused Murray LJ to reconsider whether he was arguing from a false premise but it clearly troubled him even more than did the situation applicable to dwelling houses. His Lordship observed:-

". . . such a discretion really strikes at the whole basis of the mortgage transaction which is that if the borrower does not pay the lender in accordance with the relevant contract, the lender is entitled to take the security and sell it to pay himself. A further thought which occurs to me is this: if the protection for the lender under a secured loan is in effect taken away by a too liberal use of the discretion to delay enforcement, the banks and other lending institutions in this country may become quite unwilling to lend their money in situations where up to now they have been willing to do so, and if this occurs such a development could produce highly undesirable results and indeed hardship for prospective home buyers or persons seeking business loans." 24

While this passage may have included some unthinking acceptance of typical banks' doomsday propaganda, it does reinforce the feeling of discomfort about the discretion which the literal reading of the legislation appears to confer. Murray LJ's solution, exercising the discretion analogously to dwelling house cases, is no more convincing than the proposed solution for dwelling house cases. ${ }^{25}$

22 Allied Irish Banks plc $\mathrm{v}$ McAllister was this kind of case. Murray LJ was only considering the position of dwelling house properties because the Master (Enforcement of Judgments) had erroneously assumed it was such a case.

23 Birmingham Citizens Permanent Building Society v Caunt [1962] Ch 883.

24 [1993] NI 286 at 300-301.

${ }^{25}$ Murray LJ suggested that a stay of enforcement could be granted where (a) the mortgagor demonstrates an ability to pay off the mortgage debt within a reasonable time, and (b) where he or she undertakes to carry out such revised terms for repayment of the debt as the court (sic Master) fixes. The discretion could also be exercised in cases of particular hardship, e.g. where illness or unemployment had undermined the mortgagor's financial position but there was still a real possibility that given extra time the mortgage payments could be managed. The six years allowed by the Master was not regarded as reasonable for a debt of over $£ 11,000$. A stay of two months was given, in part because the mortgagor had been allowed to stay in the property for several years after the original possession order. See [1993] NI 286 at 301. 
This judgment demonstrates all the limitations of a literal approach to statutory interpretation. The reliance upon the words "subject to any other statutory provision" in article 13(f) should have led the learned judge away from the conclusion he arrived at. If these words can be used to reduce in scope an Enforcement of Judgments Office discretion because something similar exists at the pre-judgment stage, it would seem to follow that there is no way of reducing the Office's discretion where none is conferred on the court. In Allied Irish Banks plc v McAllister there was a comprehensive failure to appreciate the qualitative difference between enforcing a money judgment and a judgment for the possession of land. In the former questions about hardship or the debtor's ability to pay have scarcely any relevance at the pre-judgment stage. All the court is concerned with is whether the defendant is obliged to pay the money. In cases involving the possession of land questions of hardship and anything else going to the heart of whether possession should be given to the applicant are inextricably linked to the court's decision. They have very little to do with enforcement, as the passage quoted above from the Anderson Report demonstrates. Another difference of importance is that money judgments can be enforced in a variety of different ways so it is understandable why all questions regarding payment of the debt are not necessarily resolved at trial. By contrast only one method is provided by the 1981 Order for the enforcement of judgments for the possession of land.

The unsatisfactory implications of Allied Irish Banks plc v McAllister were partly, but by no means completely, resolved by the subsequent decision of Girvan $\mathrm{J}$ in Halifax plc v Seawright and Seawright. ${ }^{26}$ This case was an appeal brought against the Master (Enforcement of Judgments)'s decision to adjourn mortgagee possession proceedings in a dwelling house case. The Master had thus purported to exercise the discretion which Murray LJ implicitly recognised in Allied Irish Banks plc v McAllister.

In coming to a very different conclusion to Murray LJ in the earlier case, Girvan $J$ attempted to distinguish the two cases. While recognising that Murray LJ's reasoning implicitly recognised the existence of an Enforcement of Judgments Office discretion in dwelling house cases, his Lordship contended that Allied Irish Banks plc v McAllister was actually a nondwelling house case. ${ }^{27}$ While this is technically correct it is a most unsatisfactory basis for distinguishing the two cases because the reasoning supporting an enforcement discretion in non-dwelling house cases is, if anything, weaker than for dwelling house cases. In relation to the latter Girvan J's judgment effectively removed the foundations altogether.

His Lordship offered two reasons for his belief that the Master (Enforcement of Judgments) has no discretion to stay or adjourn enforcement in mortgagee possession cases involving dwelling houses. First, his Lordship pointed out that the basis for limiting that discretion by reference to section 36 of the 1970 Act and section 8 of the 1973 Act was false. The discretion conferred by section 36 (which is amended by section 8), so far as it applies to the High Court in Northern Ireland, is conferred on a judge of the High Court. ${ }^{28}$ The

26 [2000] NIJB 71.

27 Ibid at 76.

28 By section 36(6). 
Master (Chancery) can exercise the discretion because section 16(3) of the Judicature (Northern Ireland) Act 1978 vests in the High Court generally the jurisdiction vested in a judge of the High Court under any statutory provision. The Master (Enforcement of Judgments) is not a High Court Master, even though article 15 of the 1981 Order gives orders of the Enforcement of Judgments Office the like effect as orders of the High Court. ${ }^{29}$ Thus the Master (Enforcement of Judgments) cannot exercise the discretion conferred by section 36 , either for the first time or after the court has already done so. It would seem to follow from this that there is no power to stay or adjourn enforcement under article 53 by reference to section 36 .

The second reason offered by Girvan $\mathrm{J}$ for rejecting the discretion for dwelling house cases reflects much of the reasoning presented in this article. This was that the Master (Enforcement of Judgments) would be acting as a further appellate court from decisions of the High Court. Of course, there might be a relevant change of circumstances between the grant of the court order and the enforcement application but the proper way to deal with that would be to make further application to the High Court for a stay of the possession order. ${ }^{30}$

Before leaving the decision in the Seawright case one further matter, which was raised by that case, should be discussed. At the end of his judgment Girvan J observed that a court order for the possession of land is capable of being enforced by committal for contempt, provided it is endorsed with a penal notice and specifies a date by which delivery of possession should be effected. ${ }^{31}$ Indeed the learned judge had made two previous rulings to this effect in proceedings under Rules of the Supreme Court (Northern Ireland) 1980, Order 113 against persons trespassing in public rented accommodation. ${ }^{32}$ Assuming the existence of this procedure it is another sign that the discretion recognised in Allied Irish Banks plc $\mathrm{v}$ McAllister is dubious, both in mortgagee possession cases and others seeking the possession of land.

The availability of contempt as an enforcement mechanism for land possession cases is not completely satisfactory. Rules of the Supreme Court (Northern Ireland) 1980 Order 45, rule 3 clearly confirms the availability of this process in article 53 cases $^{33}$ but it is still something of a relic of the days before the current enforcement system came into effect. It is not without significance that the two cases referred to above in which Girvan $\mathbf{J}$ recognised the availability of committal as a means of enforcement of orders for the delivery of possession of land were squatter cases under Order 113. In those cases rule 103(6) of the 1981 Rules specifically provides that the

29 [2000] NIJB 71 at 75-76.

30 Ibid at 76-77.

31 Ibid at 77.

32 Northern Ireland Housing Executive v Magee [1995] NI 97; Northern Ireland Housing Executive v Devine [2000] 4 BNIL 65.

33 The wording of rule 3 is - "Without prejudice to Article 53 of the Order of 1981 . . . a judgment or order for the giving of possession of land may be enforced in a case in which rule 4 applies by an order of committal under Order 52." Rule 4 provides that the act which the court order requires to be done (in this context the delivery of possession of land) must be one which the court has required to be done by a specified date. 
Office may grant no stay of enforcement. Committal for contempt has been preserved for money judgments so it might be thought strange if the ultimate enforcement power did not exist for the most common type of non-money judgments. But for money judgments there is clear recognition of the committal power for the deliberately obstructive debtor in article 107 of the 1981 Order. Rules of Court have also been made to set out the procedure to be followed in these cases. ${ }^{34}$ The same should be done for land possession cases and the provision made should be by way of enforcing orders made under article 53. The article 53 procedure should not be by-passed and if it is not working effectively it should be amended so that it can perform the function intended of it.

There are two further reasons to doubt the appropriateness of proceeding by way of contempt. First, committal does not produce possession of the lands. The defendant may prefer to go to prison and still refuse to quit possession. The applicant has no power of forcible entry, this means of enforcement being conferred only on enforcement officers under article 53. Secondly, it may be doubted whether committal would be permitted under the Human Rights Act 1998 and article 5(1)(b) of the European Convention on Human Rights. The latter provision sanctions the detention of a person to secure compliance with a court order but the need for proportionality between means and ends must cast considerable doubt on the validity of committal when another less drastic and arguably more effective means of enforcement is available. ${ }^{35}$

\section{Evaluation and Conclusion}

This article has been principally concerned with mortgagee possession cases but there is no reason to suppose that the same principles discussed here would not also apply to other cases where an order for the delivery of possession of land under article 53 of the 1981 Order is sought. Thus where the landlord of a dwelling house seeks to recover exclusive possession of the property from the tenant a court order must be obtained under articles 55-56 of the Rent (Northern Ireland) Order 1978. This procedure applies to private and public sector rented accommodation. ${ }^{36}$ It provides the appropriate time for the court to consider any application for relief from forfeiture ${ }^{37}$ or any adjournment or stay of proceedings. For business tenancies the Business Tenancies (Northern Ireland) Order 1996 only provides relief for some tenants against the landlord's refusal to grant a new lease. An existing lease can be forfeited without a court order but the tenant would have the right to apply to the court for relief against forfeiture. ${ }^{38}$ Again this would seem to be all the protection against recovery of possession which the tenant should get.

34 Rules of the Supreme Court (Northern Ireland) 1980, Order 111; County Court Rules (Northern Ireland) Order 40 Part III.

35 See McVeigh v United Kingdom (1981) 25 DR 15 at p 42.

36 Art. 55 applies to cases where the lease is subject to a right of re-entry or forfeiture and any person is lawfully residing in the premises or any part of them. Art 56 applies where the tenancy has come to an end but the occupier continues to reside in the premises or any part of them.

37 Conveyancing Act 1881 section 14(2). This would seem to apply only to art 55 proceedings.

38 Ibid. 
In relation to mortgagee possession cases involving dwelling houses it is interesting to note the decision of the English Court of Appeal in Ropaigealach $\mathrm{v}$ Barclay's Bank plc. ${ }^{39}$ This case establishes that a mortgagee seeking possession of land including a dwelling house may take possession of the property without first seeking a court order. The argument that section 36 of the 1970 Act impliedly required an application to the court was rejected. Effectively the Court of Appeal held that if the mortgagee applies for a possession order the court must consider the exercise of its statutory discretion but if the mortgagee makes no such application the mortgagor is deprived of that protection. Admittedly the circumstances of that case were somewhat special. The mortgagee did not attempt to sell the land with vacant possession and was only able to obtain physical possession because the occupiers of the property had left. To the extent that this case deprives mortgagors of dwelling houses of protection against the loss of their occupation rights it might be open to challenge under articles 6 and 8 of the European Convention on Human Rights. ${ }^{40}$ However it does not mean that the Enforcement of Judgments Office should attempt to make up for any perceived deficiency in the pre-judgment law by exercising a discretion under article 53 of the 1981 Order, when the true construction of that Order indicates that no such discretion exists.

When a court or tribunal orders a defendant to give possession of land to another person this should finally settle the questions of whether and when possession is to be given. The only exception to that should be that a court or tribunal which has the power to stay proceedings or the enforcement of its order, should be allowed to take a fresh look at the matter should circumstances change after the grant of the order. On no account should the Enforcement of Judgments Office be examining questions like this. Judgments or orders giving possession of land are quite different from money judgments. No examination of the defendant as to ability to pay is required and the Office has no choice of enforcement methods. There is nothing to justify delay in making an order under article 53 of the 1981 Order.

The two cases discussed at length in this article, Allied Irish Banks plc $v$ McAllister and Halifax plc v Seawright and Seawright, have left the law in an unsatisfactory condition. Since these are two first instance decisions of the High Court the formal position is that the Office can grant a stay or adjournment in mortgagee possession cases where the land does not include a dwelling house but cannot do so where it does include a dwelling house. In possession cases not brought by mortgagees, e.g. landlords, there is no indication whether the Office has any discretion in the matter. In principle it should not because the reasoning in the Seawright case, by far the more satisfactory of the two rulings, strongly suggests that stays and adjournments are history by the time proceedings get beyond the court.

What should the Enforcement of Judgments Office do in the face of this conflict of authority? It surely cannot wait for the Court of Appeal to resolve the conflict and apply McAllister in non-dwelling house mortgagee cases and Seawright in the dwelling house cases in the meantime. It ought to make the

39 [2000] 1 QB 263.

40 As implemented in domestic law by the Human Rights Act 1998. 
article 53 order in all cases, including non-mortgagee cases, with all deliberate speed, and leave any occupier aggrieved with the decision to institute an appeal which might end in the Court of Appeal. In correspondence with the author the Master (Enforcement of Judgments) has confirmed that since Seawright he regards his article 53 powers as limited to granting a stay only to enable the occupier of property to apply to the court which granted the possession order for a stay on such terms as to the court may seem fit.

In the face of these difficulties one cannot blame litigants anxious to obtain possession of property from instituting contempt proceedings but the relationship between the latter and the enforcement of judgments' legislation is not satisfactory. There should be amendment of this legislation, the 1981 Order and the Rules, to provide that the Office should proceed to deliver possession of the land to the person entitled to it under the judgment. Article 53 should be amended to make clear that the Office must make an order for delivery of possession where a judgment (not subject to any current stay of enforcement) grants this to the applicant. The procedure in Rule 35(2) whereby any person in occupation of the land may seek a hearing before the Master to object to the delivery of possession should be abolished because this is simply a request for the exercise of a discretion which does not exist. The procedure under Rule 35(1), under which notice of the intention to make the article 53 order is given to the occupiers, should be retained because they should be given the opportunity to make whatever alternative arrangements they can and possibly apply to the court for a stay of enforcement of the judgment. The committal power under Rules of the Supreme Court (Northern Ireland) 1980 Order 45 should be abolished, save for a residual power to commit anyone who wilfully attempts to frustrate the implementation of an order under the proposed new article 53 procedure. Apart from that the remaining provisions relating to the enforcement of judgments for possession of land should be retained. 